\title{
PERFORMANCE OF ISLAMIC BASED SCHOOL TEACHERS IN TEMBALANG SUB-DISTRICT, SEMARANG CITY AFFECTED BY INTELLECTUAL INTELLIGENCE AND SPIRITUAL INTELLIGENCE
}

\author{
Anis Turmudhi \\ Lecturer STIE AKA Semarang
}

Diterima: November 2018. Disetujui: Desember 2018. Dipublikasikan: Januari 2019

\begin{abstract}
This Research has a background from several teacher education qualifications that are not yet in accordance with the teacher's education qualifications that should be a teacher. The focus of the problem in this research is the influence of intellectual intelligence and spiritual intelligence on teacher performance partially and simultaneously. So the purpose of this research is to analyze and explain the influence of two intelligence variables partially and simultaneously on the performance of Islamic based elementary school teachers in Tembalang District, Semarang City.

This research method uses quantitative analysis. The number of samples is 87 people, so the data collection uses total sampling technique. Data collection techniques with questionnaires, and data were tested using multiple regression analysis.

The results of the study were intellectual intelligence that had a positive but not significant effect on teacher performance. Spiritual intelligence has a positive and significant effect on teacher performance. As well as intellectual intelligence and spiritual intelligence together have a positive and significant effect on the performance of Islamic based elementary school teachers in Tembalang District, Semarang City. The limitations in this study are that there is little time and minimal funding.
\end{abstract}

Keywords: intellectual intelligence, spiritual intelligence, and teacher performance

\section{Introduction}

Many people say that Islamic education in Indonesia is as old as the growth and development of Muslims in the archipelago. Before the 90s, Islamic Education Institutions were represented by Islamic boarding schools and madrasas. After the reform era in the late 90s, Islamic Education Institutions began to develop with the concept of an Integrated Islamic School.

Functionally, the three educational institutions (Islamic boarding schools, madrasas and integrated Islamic schools) are expected to be a forum for galvanizing the mental, moral and spiritual of the younger generation, who are prepared to be useful human beings for religion, religion and nation. While substantially the three Islamic educational institutions have a very strategic role, namely the call of the spiritual soul of a cleric, cleric or teacher, which is not solely based on material motives, but as a dedication to Allah SWT. This is in line with the goal of Islamic education revealed by Al-Ghozali, which is to get closer to Allah, not solely for rank or dignity (Ihsan: 2008) 
Integrated Islamic Schools began to emerge and develop after the reform era in the late 90s. Integrated Islamic Schools emerged as an alternative solution to the restlessness of some Muslim communities who wanted an Islamic education institution that was committed to practicing Islamic values in its system, aimed at having balanced competencies between kauniyah and qauliyah, between fikriyah, ruhiyyah and jasadiyyah, so able to give birth to a young generation of knowledge, knowledgeable and useful for the people, nation and state of Indonesia. This Integrated Islamic School has the aim of creating students who possess Intellegen Quotient (IQ), Emotional Quotient (EQ) and high Spiritual Intelligence (Spiritual Quotient / SQ) and good work ability (ihsan). To realize the goal so that students have 3 (three) such intelligence, then an ustadz or teacher must also have these three intelligences. Education will be easily delivered to students, if students are given examples of exemplary by their teacher.

Based on Republic of Indonesia Law Number 14 of 2005 concerning Teachers and Lecturers, "Teachers are professional educators with the main task of educating, teaching, guiding, directing, training, evaluating and evaluating students, in early childhood education, formal education, education basic, and secondary education ". The teacher is the most important component of implementing education to develop student resources. According to Ho Chi Minh (t.t.) in Surya (2013), without a teacher, education will not exist, and if education does not exist, there will be no economic and social development.

Teachers are adults who have an advantage over other adult humans. The advantages in question are:

1. The teacher has been educated and prepared specifically in the field of education.

2. The teacher controls a number of knowledge and skills along with learning methodologies that can be used as a stimulus for the child's development process (Dervish: 2006).

So the teacher is the subject that has been prepared in the field of education with mastery of knowledge and skills. The provision is used by the teacher to provide education, teaching, training, mentoring, direction, evaluation to evaluation actions on the subject of education.

Not a few teachers lose their exemplary souls as educators. The exemplary soul as an educator begins to diminish and even fades. So that the teacher's motto is "digugu and imitated" has begun to disappear among the people. Likewise, there are still many 
teachers who do not upgrade themselves as educators with a lack of following developments in science and technology, so that the learning process does not keep up with the development of globalization. In addition, the reality is that teachers are only oriented towards grades in report cards or diplomas, rather than being oriented towards the work of students. This is also conveyed by Masaong (2012), that the teacher assessment system for students has not been oriented to authentic assessment (student performance).

Examples of these two cases are related to teacher performance variables, so the teacher is still lacking in fulfilling the competence of a teacher. Especially in the dimensions of pedagogic competence with indicators of the ability to utilize information and communication technology for the benefit of learning. And on the dimensions of personality competence with indicators of the teacher's ability to present himself as someone who can be a role model for students and society.

To realize the national education goals, it takes teachers (teachers) who can carry out their duties and obligations according to the Law of the Republic of Indonesia No.20 of 2003, education providers in Indonesia are a national education system that is systematically regulated national education functions to develop abilities and forms of character and a dignified nation of civilization in order to educate the life of the nation, aiming at the development of potential students to become human beings who believe and fear God Almighty, have noble character, knowledge, skillful, creative, independent and become democratic and responsible citizens.

Based on the problems of the teacher in the field of education and mandate of the Law, all of which the researchers have described in the background above, it is necessary to study in the form of research for teachers, especially for teachers in Islamic-based elementary schools in the City of Semarang. The researcher conducted a study entitled "The Work of Islamic Based Primary School Teachers in Tembalang District, Semarang City Affected by Intellectual Intelligence and Spiritual Intelligence".

\section{Problem Formulation}

Based on the background and problems mentioned above, several research questions can be formulated as follows

1. How does the influence of intellectual intelligence on the performance of Islamic-based elementary school teachers in Tembalang District, Semarang City? 
2. What is the influence of spiritual intelligence on the performance of Islamic based elementary school teachers in Tembalang District, Semarang City?

3. What is the influence of intellectual intelligence and spiritual intelligence together on the performance of Islamic-based elementary school teachers in Tembalang City, Semarang?

\section{STUDY OF THEORY \\ Intellectual Intelligence}

Andrew Crider said that intelligence is like electricity, easy to measure but almost impossible to define (Crider et al. In Azwar: 2008). Whereas H. H. Goddard defines intelligence as the level of ability of one's experience to solve problems that are directly faced and to anticipate future problems (Goddard in Azwar: 2008).

According to David Weehsler, intelligence is the ability to act in a direction, think rationally and deal with its environment effectively (Weehsler in Azwar: 2008). So that in broad outline it can be concluded that intelligence is a mental ability that involves the process of thinking rationally. Therefore intelligence cannot be observed directly, but must be inferred from various concrete actions which are manifestations of the process of rational thinking.

Wiramiharja has conducted research on intelligence and willingness to work performance. He examined intelligence by using intelligence tests taken from intelligence tests, (Lauster in Wiramiharja: 2009), while measuring the amount of willingness using the Pauli test tool (Pauli in Wiramiharja: 2009). Specifically concerning the amount of addition, he mentions three dimensions of intellectual intelligence that concern the three cognitive domains. The three dimensions are: (Wiramiharja: 2009).

a. The ability of figures is an understanding and reason in the field of form.

b. Verbal ability is an understanding and reason in the field of language.

c. Numerical abilities, namely understanding and reasoning in the field of numerical or related to ordinary numbers.

More specifically, the manifestations of indicators of intellectual behavior are: ease in using numbers, efficiency in language, speed in observation, ease of remembering, ease of understanding relationships, and imagination 


\section{Spiritual Intelligence}

Zohar and Marshall provide the definition of spiritual intelligence which is the innate internal ability of the brain and human soul whose deepest source is the core of the universe itself, which allows the brain to find and use meaning in solving problems (Zohar and Marshall in Bowo: 2009)

The dimensions of people who have spiritual intelligence based on the theories of Zohar and Marshall and Sinetar are: (Bowo: 2009)

a. Having Self Awareness

There is a high level of awareness and depth so that you can be aware of the various situations that come and respond to them.

b. Having a vision

Yaitu memiliki pemahaman tentang tujuan hidup dan memiliki kualitas hidup yang diilhami oleh visi dan niali-nilai.

c. Be Flexible

Able to adjust spontaneously and actively to achieve good results, have a pragmatic (appropriate), and efficient view of reality.

d. Holistic Views

Seeing that yourself and others are interrelated and can see the interrelationships between things. Can view a larger life so that it is able to face and utilize, transcend misery and pain, and view it as a vision and look for the meaning behind it.

e. Make changes

Making changes that are open to differences, has the ease of working against conventions and status quo and also being a free person.

\section{f. Source of inspiration}

That is being able to be a source of inspiration for others and have fresh ideas. g. Self reflection

Have a tendency which is fundamental and basic

\section{Teacher Performance}

In terms of terminology, performance is the implementation of work tasks at a certain time and a process to achieve work results (Westra in Susanto: 2013). Performance according to the Ministry of National Education, that the performance of an employee is related to performance, work results and achievements that are shown at a certain time (Susanto: 2013). The goal is to meet the work goals of employees who will later 
contribute to the organization's goals. Teacher performance is the ability and effort of the teacher to carry out the best learning tasks in planning teaching programs, implementing learning activities and evaluating learning outcomes (Permendiknas No. 41 of 2007).

Based on the Regulation of the Minister of National Education of the Republic of Indonesia Number 41 of 2007, concerning Process Standards for Primary and Secondary Education Units. Article 1 Paragraph (1) states that: Standard processes for primary and secondary education units include planning the learning process, implementing the learning process, evaluating learning outcomes, and monitoring the learning process.

Based on the above parameters, the following framework can be drawn up:

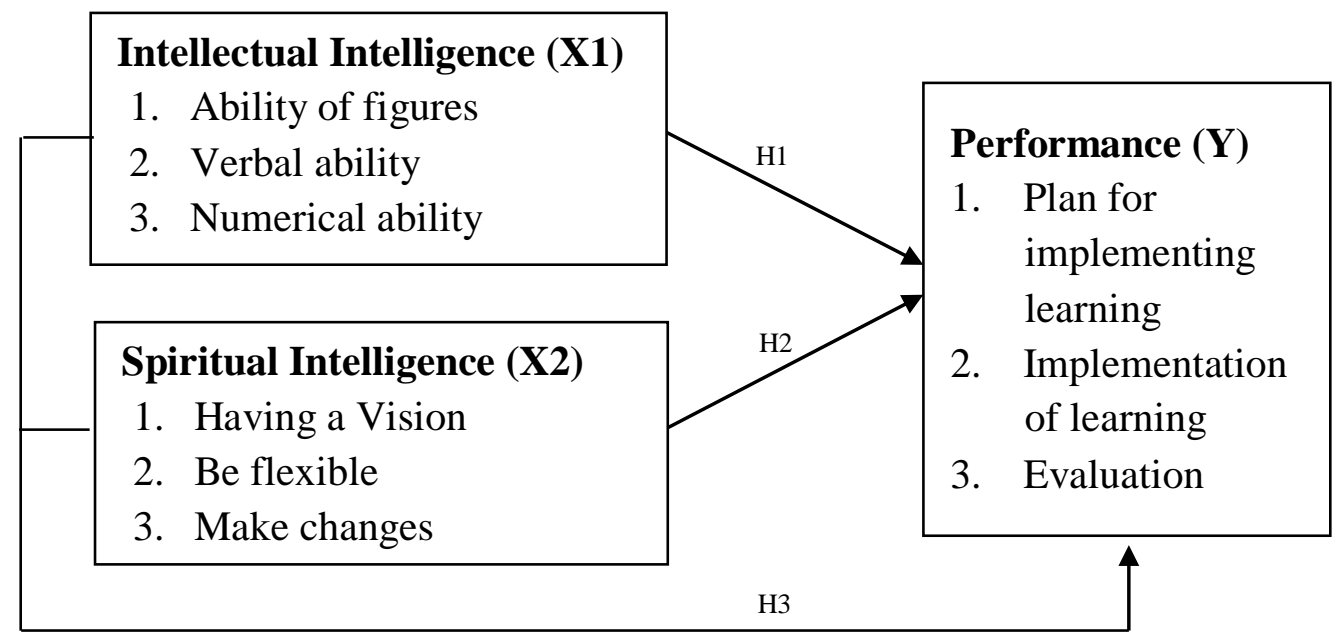

\section{RESEARCH METHODS}

\section{Population and Samples}

The population in the study were Islamic based elementary school teachers in Tembalang District, Semarang City under the Semarang City Education Service. Efforts to obtain the data in question were carried out by interviews and using questionnaires as instruments. Primary data in this study in the form of respondents' answers to the questionnaire given. While supporting data or secondary data in the form of teacher age, gender, class, length of work obtained from Islamic based elementary schools in Tembalang District, Semarang City. 


\section{Variable Description Analysis}

The variable description is a statistical calculation of the variables of intellectual intelligence, spiritual intelligence and teacher performance, including the total mean value, and the minimum value and the maximum value using the SPSS 16.0 for windows program.

The measurement scale used to measure questionnaire indicators uses a rating scale, which uses 4 (four) categories of details as follows :

Score 4 (SA): Strongly Agree

Score $3(\mathrm{~A})$ : Agree

Score $2(\mathrm{DA}) \quad$ : Disagree

Score $1(\mathrm{SDA}) \quad$ : Strongly Disagree

\section{Test Validity}

Testing is done using Kaiser-Meyer-Olkin Measure of Sampling Adequacy (KMO-MSA), then an indicator is said to be valid if the value of $K M O \geq 0.5$. Then these indicators can be used for further analysis

\section{Reliability Test}

The test tool used is the Cronbach alpha coefficient provided that if Cronbach's alpha coefficient is $>0.7$, then a variable / construct used is declared reliable (Ghozali: 2009)

\section{Model Testing}

\section{a. Multiple Regression Analysis}

Regression analysis is measuring strength and showing the direction of influence between independent variables on the dependent variable (Ghozali: 2009). The equations used are:

$\mathrm{Y}=\mathrm{a}+\beta_{1} \mathrm{X}_{1}+\beta_{2} \mathrm{X}_{2}+\mathrm{e}$

Where :

$\mathrm{Y}=$ Teacher performance

a $\quad=$ constant

$\beta_{1-2}=$ independent variable regression coefficient

$\mathrm{X}_{1}, \mathrm{X}_{2}, \quad=$ Intellectual Intelligence and Spiritual Intelligence

$\mathrm{e} \quad=$ Standard error 


\section{b. Test t}

The $t$ test (partial test) is used to determine whether in the regression model the independent variable partially (each variable) has a significant effect on the dependent variable. This $t$ test is required as follows :

- Ho $=$ accepted if probability significance $\geq 0.05$

- Ha = accepted if probability probability $<0.05$

\section{c. Test F}

This test is carried out using Analysis of Variance (ANOVA). The test is formulated as follows :

- Ho : b1, b2, = 0, meaning that the independent variables simultaneously do not significantly influence the dependent variable.

- Ha : b1, b2,> 0, meaning that the independent variables simultaneously have a positive and significant effect on the dependent variable.

Based on the formula above and with an alpha level of 5\%, the conclusions / decisions that can be made are: if the probability significancy is $<0.05$ then, Ha is accepted and Ho is rejected, and vice versa. This means that there is a significant influence between the independent variables on the dependent variable.

\section{d. Determination Coefficient Test}

The coefficient of determination is to measure how far the ability of the model to explain the variation of independent variables on the dependent variable. The small value of the coefficient of determination means that the ability of independent variables to explain variations in the dependent variable is very limited. A value close to one means that the independent variables provide almost all the information needed to predict variations in the dependent variable (Gozali: 2009).

\section{e. Test the Hypothesis}

This test is conducted to determine the effect of independent variables individually / partially on the dependent variable, the test is carried out by $t$ test. 


\section{ANALYSIS RESULTS}

\section{Test Validity}

The sample is said to be sufficient if the Kaiser-Mayor-Olkin (KMO) coefficient is greater than 0.5 ; and the indicator is said to be valid if the component matrix coefficient is greater than 0.4. In this study the requirements have been fulfilled. While testing the validity of indicators in this study that all indicators contained in the variables of intellectual intelligence, spiritual intelligence and teacher performance have a matrix coefficient greater than 0.4 . The results of this test can be described that all indicators contained in each of these variables are valid

\section{Test Reliability}

\begin{tabular}{|c|l|c|c|}
\multicolumn{5}{|c|}{ Test Reliability Indicators } \\
\hline No & \multicolumn{1}{|c|}{ Coefficient Alpha Cronbach } & Hasil & Keterangan \\
\hline 1 & Variable Intellectual Intelligence & 0,913 & Reliabel \\
2 & Variable Spiritual Intelligence & 0,953 & Reliabel \\
3 & Teacher Performance Variables & 0,917 & Reliabel \\
\hline
\end{tabular}

Based on the table above, it can be seen that Alpha Cronbach's coefficient of intellectual intelligence, spiritual intelligence and teacher performance, all of them are $\geq 0.7$. These results can be described that the sample in this study is reliable

\section{Multiple Regression Analysis}

The results of the analysis, obtained regression coefficient of intellectual intelligence variable $(\beta 1)$ of 0.059 ; The regression coefficient of spiritual intelligence variable $(\beta 2)$ is 0.826 ; then the multiple regression equation is :

$$
\begin{array}{r}
Y=\beta_{1} X_{1}+\beta_{2} X_{2}+e \\
=0,059 X_{1}+0,826 X_{2}
\end{array}
$$

Can be explained that :

a. Variables of intellectual intelligence have a positive effect on the performance of Islamic based elementary school teachers in Tembalang District, Semarang City

b. Variables of spiritual intelligence have a positive effect on the performance of Islamic-based elementary school teachers in Tembalang District, Semarang City

\section{Test F}

ANOV A

\begin{tabular}{|l|l|l|l|l|c|}
\hline Model & Sum of Squares & df & Mean Square & F & Sig. \\
\hline
\end{tabular}




\begin{tabular}{|ll|r|r|r|r|r|}
\hline 1 & Regression & 1918.169 & 2 & 959.085 & 130.305 & $.000^{\mathrm{a}}$ \\
& 618.268 & 84 & 7.360 & & \\
& Residual & 2536.437 & 86 & & & \\
\hline
\end{tabular}

a. Predictors: (Constant), Spiritual Intelligence, Intelektual Intelligence

b. Dependent Variable: Teacher Performance

Regression equation has $\mathrm{F}$ count $>\mathrm{F}$ table $(130.305>3.10)$ and significance $\mathrm{F} \leq 0.05$. These results can be described that the variables of intellectual intelligence and spiritual intelligence jointly influence the performance of Islamic based elementary school teachers in Tembalang District, Semarang City.

\section{Determination Coefficient Test}

\section{Determination Coefficient Test} Model Summary

\begin{tabular}{|l|r|r|r|c|}
\hline Model & $\mathrm{R}$ & $\mathrm{R}$ Square & $\begin{array}{c}\text { Adjusted R } \\
\text { Square }\end{array}$ & $\begin{array}{c}\text { Std. Error of the } \\
\text { Estimate }\end{array}$ \\
\hline 1 & $.870^{\mathrm{a}}$ & .756 & .750 & 2.71299 \\
\hline
\end{tabular}

Source: primary data processed in 2018

Regression equation has an adjusted $\mathrm{R}$ square of 0.750 . These results can be described that intellectual intelligence and spiritual intelligence are jointly able to influence variations in variable changes in the performance of Islamic based elementary school teachers in Tembalang City, Semarang District, up to 75\%. The remaining $25 \%$ of the performance of Islamic-based elementary school teachers in Tembalang District, Semarang City is influenced by other variables not included in this study.

\section{Test of Hypotheses}


The hypothesis test in this study uses the $t$ test, if the significance of $t$ is smaller than $5 \%$, the independent variables partially have a positive and significant effect on the dependent variable. Based on data processing, the following results are obtained :

a. The significance of the $t$ variable of intellectual intelligence on teacher performance is 0.455 . This number is greater than 0.05 , so it can be described that the hypothesis is rejected. This means that intellectual intelligence variables have a positive but not significant effect on the performance of Islamic based elementary school teachers in Tembalang District, Semarang City.

b. The significance of the variable of spiritual intelligence on teacher performance is 0,000 . This number is less than 0.05 , so it can be described that the hypothesis is accepted. This means that the variable spiritual intelligence has a positive and significant effect on the performance of Islamic based elementary school teachers in Tembalang District, Semarang City.

\section{Discussion}

Based on the processing of the data above, discussion can be carried out as follows :

a. Effect of intellectual intelligence on teacher performance

The regression coefficient of intellectual intelligence variables on teacher performance is 0.059 with a significance level of 0.455 . The results of this study indicate that intellectual intelligence has a positive but not significant effect on teacher performance. This means that the higher the level of intellectual intelligence of a teacher the effect is not significant on the performance of Islamic-based elementary school teachers in Tembalang District, Semarang City.

b. Effect of spiritual intelligence on teacher performance

The regression coefficient of spiritual intelligence variables on teacher performance is 0.826 with a significance level of 0.000 . The results of this study indicate that spiritual intelligence has a positive and significant effect on teacher performance. This means that the better the level of spiritual intelligence of a teacher the better the performance of Islamic-based elementary school teachers in Tembalang District, Semarang City. 
c. Effect of Intellectual Intelligence and Spiritual Intelligence together on Performance

The results of the $\mathrm{F}$ test conducted in this study indicate that the regression equation has $\mathrm{F}$ count $>\mathrm{F}$ table $(130.305>3.10)$ and significance $\mathrm{F} \leq 0.05$. It can be described that the variables of intellectual intelligence, emotional intelligence and spiritual intelligence jointly influence the performance of Islamic based elementary school teachers in Tembalang District, Semarang City.

\section{CONCLUSIONS AND RECOMMENDATIONS}

\section{Conclusion}

Based on the results of data analysis, it can be concluded as follows :

a. There is an influence of intellectual intelligence on the performance of Islamic-based elementary school teachers in Tembalang District, Semarang City but not in accordance with the reality in the field.

b. There is influence and in accordance with the reality in the field between spiritual intelligence towards the performance of Islamic-based elementary school teachers in Tembalang District, Semarang City.

c. There is influence and in accordance with the reality in the field between intellectual intelligence and spiritual intelligence together towards the performance of Islamic-based elementary school teachers in Tembalang District, Semarang City.

\section{Suggestions}

a. To the Management of the Foundation that oversees the school, and the Principal, if a comparative study can be held to the place of the school that has exemplary and outstanding teachers.

b. The Principal can always send his teacher to attend the motivational workshop and seminar.

c. The Foundation Management and School Leaders must regularly schedule religious studies.

d. In an effort to form students who can master intellectual intelligence and spiritual intelligence, the teacher must give an example first in mastering 2 (two) of these 
intelligences. By practicing these two intelligences, the teacher's performance will automatically increase. Therefore the researcher suggested that the Education Office and Management of the Foundation overshadow the school, so that they could issue a policy on the assessment of the implementation of these two intelligences by teachers in elementary schools, especially Islamic based ones.

\section{Limitations of Research and Recommendations}

In this study, researchers have limited time and limitations in financing. Which can be recommended in this study, can still be further investigated about other variables that can affect teacher performance, because the two variables in this study can affect together only by $75 \%$.

\section{REFERENCE}

Agustian, Ary Ginanjar. Rahasia Sukses Membangun Kecerdasan Emosional dan Spiritual The ESQ Way 1651 Ikhsan Rukun Iman dan 5 Rukun Islam, Cetakanke-33, Jakarta, Arga Wijaya Persada, 2006.

Arikunto, Suharsini, Prosedur Penelitian (Suatu Pendekatan Praktek), Edisi Revisi VII, Jakarta, Rineka Cipta, 2006

Armstrong, Michael. Managing People, Jakarta, Bhuana Ilmu Populer, 2003

Azwar, Saifuddin, Drs, MA. Pengantar Psikologi Intelegensi, Cetakan ke-VI Yogyakarta, Pustaka Pelajar, 2008.

Efendi, Agus, Revolusi Kecerdasan Abad 21, Bandung, Alfabeta, 2009

Ghozali, Imam. Aplikasi Analisis Multivariate Dengan Program SPSS, Semarang, Universitas Diponegoro, 2005

Goleman, D, Kecerdasan Emosi : Mengapa Emotional Intelligance Lebih Tinggi Dari pada IQ, Jakarta, Gramedia Pustaka Utama, 2000.

Hendriani, Susi, dan Garnasih, Raden Lestari. Pengaruh Kecerdasan Intelektual dan Kecerdasan Emosional Terhadap Kinerja Guru SMA $N 8$ Pekanbaru, Riau, Universitas Riau, 2013.

Indrianti, Wahyu, Dra, M.Si, dkk. Psikologi Pendidikan Membantu Siswa Tumbuh dan Berkembang (terjemahan), cetakan ke-VI, Jakarta, Erlangga, 2009

Mulyasa, H.E, Prof, Dr, M.Pd. Uji Kompetensi dan Penilaian Kinerja Guru, Cetakan kedua, Bandung, Remaja Rosdakarya, 2013

Paisal dan Anggraini, Susi. Pengaruh Kecerdasan Emosional dan Kecerdasan Spiritual Terhadap Kinerja Karyawan Pada LBPP-LIA Palembang, Palembang, Poleteknik Negeri Sriwijaya, 2010. 
Peraturan Menteri Pendidikan Nasional Nomor 16 Tahun 2007 Tentang Standar Kualifikasi Akademik dan Kompetensi Guru, Jakarta, Pustaka Karya, 2007

Purwanto, Edy, Dr, M.Si. Metodologi Penelitian Kuantitatif, Yogyakarta, Pustaka Pelajar, 2016

Rahmasari, Lisda. Pengaruh Kecerdasan Intelektual, Kecerdasan Emosi dan Kecerdasan Spiritual Terhadap Kinerja Tulungagung, Tulungagung, STIKIP PGRI, 2015.

Sholiha, Milatus, dkk. Pengaruh Kecerdasan Emosional dan Kecerdasan Spiritual Terhadap Kinerja Guru SMP An-Nur Bululawang - Malang, Malang, Universitas Islam Malang, 2017

Sugiyono, Prof, Dr. Metode Penelitian Pendidikan (Pendekatan Kuantitatif, Kualitatif, dan $R \&$ D, ) Cetakan ke-11, Bandung, Alfabeta, 2015

Sutomo, Y. Strategi Peningkatan Kinerja Pegawai, Semarang, Amindo, 2014.

Suyatno. Revolusi Organisasi Dengan Memberdayakan Kecerdasan Spiritual, Yogyakarta, Andi Offset, 2006

Undang-Undang Republik Indonesia Nomor 14 Tahun 2005 Tentang Guru dan Dosen, Jakarta, Pustaka Karya, 2006

Yudistiro, Indra Agung, Pengaruh Kecerdasan Emosional, Lingkungan Kerja, dan Disiplin Terhadap Kinerja Guru Dengan Komitmen Organisasi Sebagai Moderasi, Surakarta, Universitas Slamet Riyadi, 2015.

Zohar, Danah dan Marshall, Ian. Spiritual Intelligence The Ultimate Intelligence, Great Britain, Bloomsberry, 2000 